\title{
Is Africa Capable of Achieving the Sustainable Development Goals in the 2020-2030 Decade of Programming?
}

\author{
Austin Muswere (Corresponding Author) \\ College of Peace, Leadership and Governance \\ E-mail: muswerea@africau.edu; austinmuswere@gmail.com
}

Received: Jun. 18, 2020 Accepted: Sep. 17, 2020 Online published: Nov. 1, 2020

doi:10.5296/jpag.v10i4.17209～URL: https://doi.org/10.5296/jpag.v10i4.17209

\begin{abstract}
The capabilities, efficiency and effectiveness of the outcomes of the African Regional Forum on Sustainable Development demands a lot of analytical work from an African perspective towards its commitment on achieving the Sustainable Development Goals in the 2020-2030 decade. This paper provides an analytical framework questioning the forum's outcomes and the African capabilities. The framework interrogates the feasibility of the approaches of the forum used as alternatives towards the achievement of the 17 sustainable development goals, 169 targets and 304 indicators. The analysis is made together with the outlook of the African aspirations as defined in the Agenda 2063. An analytical framework based on advocacy research and desk review of literature available was used. The framework provided a balanced analysis of both the progress made so far and the challenges that Africa is facing today. Africa does not have effective strategies that make her ready to meet the sustainable development goals by 2030. Africa is recommended to prioritise on investment, build strong partnerships and coalitions as a critical discernment of the different African initiatives propagated through the 2030 Agenda and 2063 Agenda.
\end{abstract}

Keywords: 2020-2030 decade, 2063 agenda, African regional forum, agenda 2030, sustainable development goals

\section{Introduction}

The capabilities, efficiency and effectiveness of the outcomes of the African Regional Forum on Sustainable Development (ARFSD) are worth mentioning in examining Africa's commitment on achieving the Sustainable Development Goals (SDGs) in the 2020-2030 decade of programming. The 2020-2030 decade has been singled out as a period of greater commitment by African countries to enhance its social, economic and environmental 
transformations (Shi, Han, Yang \& Gao, 2019). Achievement of social, economic and environmental development forms part of the pillars of sustainable development (Cerf, 2018; Shi, Han, Yang \& Gao, 2019; Mensah, 2019). According to Mensah (2019), sustainable development has become a popular phrase in contemporary development discourse. Considerably, the following questions are important in the analysis of the approaches of the forum. How informative and effective are the ARFSD approaches? Does the High Level Panel dialogue help to enhance measures to accelerate implementation of the 2030 Agenda and Agenda 2063 within the 2020-2030 decade? Was there greater insight into the progress made on the implementation of the 2030 Agenda and Agenda 2063 in Africa?

The African Regional Forum for Sustainable Development (ARFSD) is a multi-stakeholder platform convened by the Economic Commission for Africa (ECA) in collaboration with the regional organizations and the United Nations system (UNECA, 2020). The platform seeks to review progress, share experiences, build consensus on how the continent can advance the implementation of the 2030 Agenda for Sustainable Development (SD) and goals set out in African Union`s Agenda 2063 (UNECA, 2020). The 17 sustainable development goals (SDGs), 169 targets and 304 targets (Jolly \& Santos, 2016; Shumba, 2017) were published in 2015 at the United Nations Summit to guide the role of the public, profit and non-profit making, private, state actors, non-state actors and voluntary sectors in global development (Jaiseyimi, 2016; SDG Centre for Africa and Sustainable Development Solutions Network, 2019). Shumba (2017) implores that the SDGs are comprehensive in their purpose to foster economic growth, promote environmental protection and end extreme poverty, fight inequalities and social injustices. Shumba (2017) reinforced that to enhance implimentationality of the SDGs, governance was appended to economic, social and ecological dimensions of sustainable development.

Furthermore, Sustainable development goals are regarded as a set of global policies to have originated from the contributions of multiple actors stepping beyond the horizons of the developed countries and the top-down approaches of the United Nations (Jolly \& Santos, 2016). They are a wide range of global sustainable development targets for the environment, economy and society launched by the United Nations in 2015 (Johnes, Wynn, Hillier \& Comfort, 2017). The SDGs are universal as they apply to all countries, assembled through an unprecedented process of participation of country by country with a strong civil society participation in countries of the South as well as countries of the North (Jolly \& Santos, 2016). Longhurst (2017) suggests that the SDGs help in developing and promoting a universal development agenda approach which addresses shared problems and challenges. This paper questions the capabilities, efficiency, effectiveness, challenges as well as suggesting effective strategies and policy recommendations meant to deliver a transformed and prosperous Africa within the 2020-2030 decade. The objectives of this research are as follows: (a) to assess the readiness of Africa to meet the sustainable development goals by 2030, (b) to determine the development challenges that Africa is facing in meeting the goals, targets and indicators of sustainable development, and (c) to propose the effective strategies and capabilities ideal for Africa to meet the SDGs by 2030. 


\subsection{Research Gap and Questions}

Africa has done a lot of development initiatives but due to a number of structural problems and challenges like poverty, instability, natural disasters and climate change no positive results are available yet that guarantee Africa to meet the SDGs within the 2020-2030 decade of programming ( UNECA, 2020). These challenges have confronted Africa negatively in such a way that foresees Africa`s developmental path decimating again if robust structural, social, economic, political and industrial reforms are not done immediately. The scourge of pandemics like HIV/AIDS, COVID-19, malaria among others have not spared Africa at all. All these areas need attention.

An analysis of Africa`s capabilities to meet the SDGs could be understood by providing an analytical framework of the African perspectives on development trajectories. These actions are guided by the approaches of the ARFSD, the readiness of the continent to fight poverty, underdevelopment and its political willingness to institute governance parameters that foster development at large. Therefore, there is need to examine the capabilities, efficiency, effectiveness of Africa to meet the SDGs by 2030. This compels asking the following questions: (a) how is Africa ready to meet the sustainable development goals by 2030? (b) What are the development challenges that Africa is facing in meeting the goals, targets and indicators of sustainable development? (c) What are the effective strategies and capabilities ideal for Africa to meet the SDGs by 2030 ?

\section{Literature Review}

The discussion in this paper revolves around the Sustainable Development Goals framework as implemented by the ARFSD. The SDGs framework is a post-2015 international socio-economic and environmental development framework that is meant to bring together human aspirations and needs to ensure a life of dignity for all (Singh, 2016; United Nations, 2016). Sustainable development goals are a set 17 goals , 169 targets and 304 indicators ( Horoszwski, 2015; Jaiseyimi, 2016; Singh, 2016; United Nations, 2016) which target to end poverty and enhance socio, economic growth, social justice and equality through use of good governance practises, infrastructure, science, technology and strong global partnerships to meet all human needs. Cerf (2018) argues that sustainable development goals are integrated, indivisible and balance the three pillars of sustainable development namely economic, social and environmental (Johnes, Wynn, Hillier \& Comfort, 2017) while adopting the principles of people, planet, prosperity, peace and partnership. The SDGs framework is premised on the concept of Sustainable Development. 


\subsection{Sustainable Development Concept}

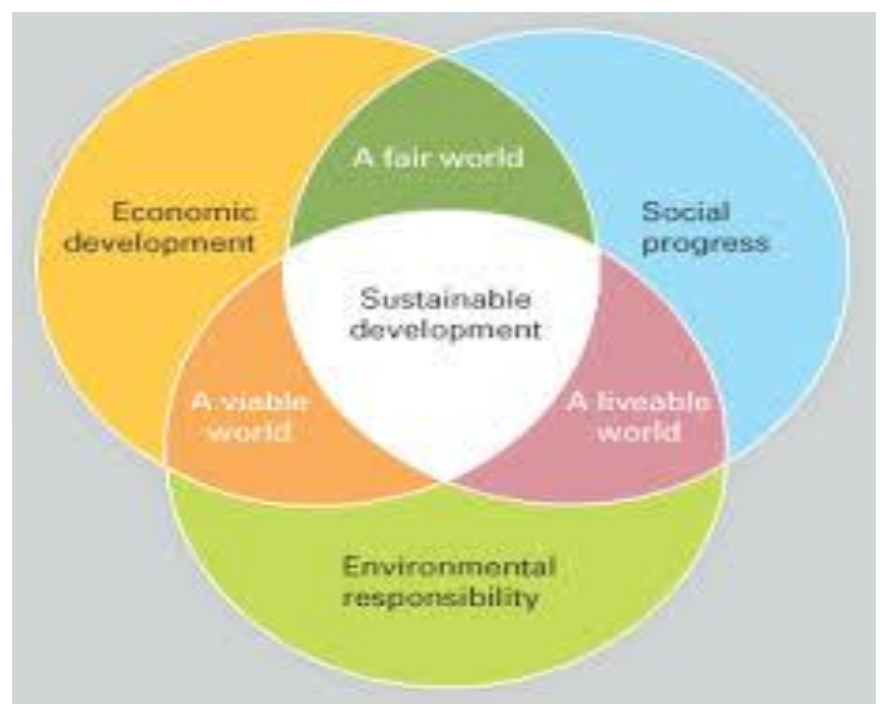

(United Nations, 2016)

The Sustainable development concept encompasses the achievement of three interconnected objectives namely; economic development, social inclusion and environmental sustainability which are necessary for the well-being of individuals and societies (United Nations, 2016; Cerf, 2018). Emas (2015) says the Brundtland Commission Report defined the concept of Sustainable development as "development that meets the needs of the present without compromising the ability of the future generations to meet their own needs". Emas (2015) argues that the foundation of sustainable development is in the inherent interdependence between long term stability of the environment and the economy. Objectively the concept aims to maintain economic advancement and progress while protecting the long term value of the environment (Emas, 2015). It should however be understood that there are various definitions of Sustainable Development and as such several misinterpretations exist. This concept gradually evolved from the initial vague definition to a global action and has contained increasingly practical actions and wisdom (Shi, Han, Yang \& Gao, 2019). There is a close link between the theory of sustainable development and other international development actions adopted over time.

The Sustainable Development theory is not divorced from the Universal Development Agenda approach, Agenda 2030 and 2063 Agenda. The linkages suggest that such approaches assist in addressing the challenges and problems such as climate change, resource degradation, migration, trafficking, shared technology, growing inequality, poverty, diseases and health pandemics, wars, instability and the rise of populism and nationalism which is undermining attempts to address many of the challenges in both the North and South (Longhurst, 2017).Africa is in the doldrums as far as these challenges are concerned.

Agenda 2063 is an African Union's development trajectory premised on a number of programming and planning initiatives linked to the long term vision for Africa. The agenda has set aspirations, goals and priorities that are linked to the SDGs concept (African Union, 2020) The aspirations as set out in the Agenda 2063 are, a prosperous Africa, based on 
inclusive growth and sustainable development, an integrated continent politically united and based on the ideals of pan Africanism and the vision of African Renaissance, an Africa of good governance, democracy, respect for human rights, justice and the rule of law, a peaceful and secure Africa, one with a strong cultural identity, common heritage, values and ethics, an African people driven development trajectory relying on the potential offered by African people especially the women and youth and an Africa that stands strong, united, resilient and influential global player and partner (Jolly \& Santos, 2016; African Union, 2020).

The 2030 Agenda for sustainable development is summarised ( Barcena, Prado, Yanez \& Perez, 2017) as a civilising, universal, indivisible and rights based agenda that proposes to "leave no one behind" and needs all sectors to be engaged in its implementation. 2030 Agenda is viewed as a transformative agenda potential enough to achieve compatibility between national policies for equality, inclusive growth, decent work, expansion of international trade, climate action and conflict prevention (Barcena, Prado, Yanez \& Perez, 2017). The Universal Development Approach is described as development for everyone, everywhere, comparative experiences and mutual learning in all direction valued "more simply as development for all” (Leach, 2016:6; Longhurst, 2017).

\subsection{Sustainable Development Theory}

The analysis provided in this research is premised on the underpinnings of the sustainable development theory. The theory of Sustainable Development appeared in the 1980s (Bettencourt \&Kaur, 2011) focusing on the coordinated development of economy, society, environment and has entered the high level political agenda of all times. Currently it has become an integral part of the international agenda and its goals are a core part of research hubs around the world (Shi, Han, Yang \& Gao, 2019). The SD theory experienced different stages of evolution from the embryotic stage (before 1972), the moulding stage 1972-1987 to the developing stage from 1987 to date (Shi, Han, Yang \& Gao, 2019).The goal of sustainable development has become more comprehensive and universal, changing from the single factor goals focusing on ecological sustainability to millennium development goals to sustainable development goals today. Mensah (2019) argues that the theory of sustainable development revolves around inter and intra-generational equity anchored essentially on three-dimensional distinct but interconnected pillars, namely the environment, economy and society (Cerf, 2018). This is based on the understanding that humanity has always depended on the services provided by the biosphere and its ecosystems as argued by Musundire (2008) that the commonly accepted model of SD provides that where the three components of SD are receiving equal treatment, sustainability will be achieved. However, the reality reveals that economic and social factors are given more attention than the environment and unsustainability results. Hence the environment needs to get more attention in order for it to sustainably support the economic and social factors if all sustainable development goals are to be achieved.

\subsection{African Trajectory of Sustainable Development}

Given the theoretical framework of sustainable development it is important to apply it in the context of African development trajectories and assess whether Africa is ready to revamp its 
development actions. The level of preparedness on the part of the African perspective needs special attention. Africa adopted the United Nations 2030 Agenda for Sustainable Development anchored on SDGs which encompass 17 goals with targets and indicators that collectively strive to improve national, regional, continental and global development (Cerf, 2018). Furthermore, the African aspirations are confined within the African Union 2063 Agenda that set forth the commitment of Africa towards its development. Both the Agenda 2030 and 2063 Agenda anchored on SDGs framework present opportunities for Africa to develop and meet the SDGs by 2030. Unlike in the past where Africa's development was driven by high prices for export commodities, discovery and exploitation of natural resources, stability and more robust governance in selected countries (Cerf, 2018), the current development trajectory needs a universal, indivisible and integrated approach as envied by the SDGs framework. However, there are structural challenges that Africa is confronted with that inhibit Africa's capacity to meet the SDGs by 2030. These challenges need also to be analysed.

\subsection{The Challenges and Problems Faced by Africa}

In view of the challenges and problems, Africa`s efforts to meet the SDGs by 2030 are negatively impacted. These challenges span from climate change, unemployment, and lack of industrialisation, gender inequalities, conflicts, instabilities, hunger and poverty among other issues (Mueller, 2008). Mueller (2008) provided an overview of challenges faced by the world today in terms of population growth, hunger, natural resources and energy. There is a lot of pressure exerted on development and environment by increasing population growth estimated to be around 9.2 billion by end of 2050 (Mueller, 2008). There are also structural challenges connected to the SDG framework, that it is too ambitious, universal, and expansive, with potential inconsistences, particularly between the socio-economic development and environmental sustainability (Stern et al, 1996; Redclift, 2005; UN SDSN 2015; ICSU \& ISSC 2015; Easterly, 2015; Spaiser et al, 2016). Swain and Wallentin, (2020) argue that these challenges are akin to a quagmire of conceptual and quantification problems and extraction of a measure of sustainable development.

\subsection{The Effective Strategies Adopted by Africa to Meet SDGs by 2030}

After an analysis of the African developmental pathways, a discussion about the problems, challenges and in view of the African initiatives, it is prudent to suggest the possible alternatives that Africa can exploit to enhance its socio, economic and environmental development. Such suggestions reveal the need to transform Africa into an economic hub, with no social injustices and inequalities. Jaiseyimi (2016) suggested that SDGs represent the best opportunity of all complexities of economic development that we face today. It is reiterated that the measure of success in implementing the SDGs in Africa is the attainment of the components of the 17 goals by 2030 which can be done provided a high level of political support is given, ownership of the programme by the countries is done, institutional and human capacity development is done, inclusive of development process, mutual accountability and policy reforms are established and sustained (Jaiseyimi, 2016). Sachs (2015) says there is need for a credible means of implementation. 


\section{Methodology}

This paper uses a systematic literature review for its methodology. The approach enables an analysis of the insight of the African perspective on the steps and progress made by Africa towards achieving the sustainable development goals as outlined in the outcomes of the ARFSD. A qualitative research methodology analysis of the ARFSD and UN reports, documents, desk research and literature review surveys was used. A persuasion for advocacy research as an approach was not resisted as the aspirations for meeting the SDGs is to create a strong, rich, united and economically integrated Africa where people are not poor, hungry and excluded. Advocacy research has been selected as it has an avowed commitment to social, economic, environmental and political change (Given, 2008) whose efforts is to bring change and improvement of people`s lives. It allows for triangulation of results (Given, 2008) as it is also best placed to be applied closely with participatory and action research. The ARFSD approaches like conferencing, workshops and side events were put on the spotlight to analyse the capabilities, efficiency and effectiveness of the African strategies towards achieving the SDGs.

\subsection{Research Limitations and Areas for Further Study}

There are structural weaknesses that are contained in this research which have been necessitated by time limitations to properly investigate on all the approaches and outcomes of the African Regional Forum on Sustainable Development. The emergency of the COVID-19 health pandemic has brought restrictions that barred movement and encouragement of lockdowns and social distancing hence face to face interviews with key informants were not done limiting access to lived experiences of country performances on development. Over relying on ARFSD documents provided a bias on the assessments of development at all costs. There is need to look at the real challenges that Africa is facing today that can stall development tomorrow. Political, social and economic governance issues need to be dealt with holistically.

\section{Findings and Discussions}

The practical approaches of the ARFSD involve workshops, conferences and organising of side events regularly. The ARFSD convenes pre-conference events organised by the major groups and other stakeholders convened prior to the main conference to discuss progress on the implementation of the SDGs by the African countries. The major groups include players from business, industry, children, youth, farmers, indigenous people, local authorities, non-governmental organisations, scientific, technological communities, women, workers' unions while the other stakeholders category include the aging, Asia Pacific communities, civil society, education, academia, lesbians, gays, persons with disabilities and volunteers (ECA,2020). Jolly and Santos (2016) say that the SDGs approach answered the concerns of representation.

Despite the SDGs approach to enhance wider consultations and involvement of stakeholders, governance played a big role towards heightening situations of risk, decreasing the resilience of the people and subsequently stalling sustainability (Shumba, 2017). The ECA, (2020) 
provided an overview to justify the mandate of the major groups' participation through a number of steps taken leading to the full consideration of the participation of the major groups and other stakeholders in complimenting governments role in implementing SDGs. Shumba (2017) supported that democracy, good governance and rule of law are essential for sustainable development. It is reaffirmed that to achieve sustainable development goals there is need for institutions at all levels that are effective, transparent, accountable and democratic with the ability to address governance challenges by Africa which assist policy makers to work towards achieving the United Nations 2030 Agenda for Sustainable Development (Farah \& Sabani, 2019). Another important segment of the ARFSD is the official session where African countries in the major groups would develop a communique that is presented during the official sessions. The official session is the main conference.

Thereafter, side events are organised by different organisations and stakeholders to discuss the numerous thematic issues that address various SDGs. Side events are parallel discussions done concurrently with major groups and other stakeholders meetings giving limitations to other potential participants or stakeholders who tend to miss quite a number of important suggestions and practical experiences. Key messages and critical issues are raised from the different thematic discussions and are raised to the official session.

One of the prominent features of the ARFSD on the structuring is the thematic breakaway sessions where about six thematic issues related to all the 17 SDGs (Cerf, 2018) are thoroughly discussed for purposes of developing key messages to be forwarded to the main conferences for adoption as resolutions. The following table summarises the sub-themes and the SDGs under discussion.

Table 1. Sub themes and SDGs under discussion

\begin{tabular}{|c|l|}
\hline Sub- theme & SDG under discussion \\
\hline 1. People & $\begin{array}{l}\text { SDG 1 (No Poverty), 2 ( Zero Hunger), 3 } \\
\text { (Good Health), 4 (Quality education), 5 } \\
\text { (Gender Equality) }\end{array}$ \\
\hline 2. Prosperity & $\begin{array}{l}\text { SDGs 7(Affordable and clean energy), 8 } \\
\text { (Decent work and Economic growth), 9 } \\
\text { (Industry, Innovation and Infrastructure), 10 } \\
\text { (Reduced inequalities), 11 (Sustainable cities } \\
\text { and communities). }\end{array}$ \\
\hline 3. Planet & $\begin{array}{l}\text { SDGs 6( clean water and sanitation), 12 } \\
\text { Responsible consumption and production), 13 } \\
\text { ( Climate action), 14 ( life below water), 15 } \\
\text { (Life on land) }\end{array}$ \\
\hline 4. Peace & $\begin{array}{l}\text { SDG 16 ( Peace, justice and strong } \\
\text { institutions) }\end{array}$ \\
\hline 5. Partnership & SDG17 (Partnership for the Goals) \\
\hline 6. Youth & Integrated in a number of SDGs. \\
\hline
\end{tabular}

Source (ECA, 2020) 
The table above reflects the linkages that exist between the sub- themes of the ARFSD and the different sustainable development goals. The people centred SDGs include end to poverty, zero hunger, good health, quality education and gender equality while prosperity oriented goals include affordable and clean energy, decent work and economic growth, industry, innovation and infrastructure, reduced inequalities, sustainable cities and communities. Peace related goals are peace, justice and strong institutions while partnership and youth thematic areas are integrated in all SDGs. Planet related goals were expanded to include clean water and sanitation, responsible consumption and production, climate action, life below water and life on land. A synthesis of these goals into thematic areas reflects the commitment and level of preparedness that Africa has on achieving the implementation of SDGs by 2030.

\subsection{The Level of Preparedness on Implementation of SDGs by African Countries in the 2020-2030 Decade}

The notion that Africa has adopted the SDGs framework alongside the 2030 Agenda and 2063 Agenda reflects that the continent is prepared to implement the SDGs and hope to meet the targets by 2030. The 2019 Africa SDG Index and Dashboard Report provides that the SDGs received wide official endorsements by African governments and have been incorporated into their national plans and actions (SDG Centre for Africa and Sustainable Development Solutions Network, 2019). However, the capacity and capability of many African countries is still limited mainly due to a number of factors. The sustainable development goals assign specific responsibilities to the rich countries including increased aid, removal of trade barriers, investment barriers and eliminate unsustainable debts of the poorest countries (Todaro \& Smith, 2011). Poverty limits development in Africa making it dependent on the developed countries for progress. The advent of the sustainable development goals approach provides that there is a framework to address a universal approach to development (Longhurst, 2017). The ARFSD outcomes on Sustainable Development Goals approaches and alternatives, like the Universal Development Approach help to address shared problems and challenges amongst the African countries and between the North and South or within the South-South approaches. Developing countries face much more crippling disease burden than the developed countries, health problems are particularly more severe in Sub Saharan Africa and that Africa is the only region where overall food security and livelihoods are deteriorating. Using the example of SDG3 meant to ensure healthy lives and promote wellbeing for all ages, Coronavirus came to destroy all efforts done by Africa to meet the goal by 2030 .

However, in view of the Agenda 2030 and 2063 Agenda, Africa needs to know how best to achieve the SDGs. A number of important emerging issues were noted during the discussions. These included whether Africa is on the right path to meet SDGs by 2030? On examining the prospects of achieving the SDGs on an African perspective, Simone \& Clark (2020) indicated that "it always seems impossible until it is done". Moatti (2020), UN expert group member evaluating on SDGs reported that "progress on most SDGs has gone into the reverse". For instance on health, the world health pandemic of Corona virus (COVID-19) has put progress in the reverse. Food insecurity is on the rise as 704 million people are in severe food insecurity worldwide and 264 million in Sub-Sahara Africa and 272 million in Southern 
Asia are food insecure (Sachs, 2019). The United Nations Secretary General, Guterres alarmed that "it is abundantly clear that a much deeper, faster and more ambitious response is needed to unleash the social and economic transformation to achieve our 2030 goals" and authors of the Global Sustainable Development Goal Report (2019) emphasized the need for a strong political will and that the commitment will be required to make the needed transformations. The results of the assessment of the key institutions on development reflect negativity on the part of achievement of the SDGs by Africa.

It is unclear why there is no sufficient progress on implementation of SDGs? Systematic change in Africa is needed for in-depth transformations. The change requires committed political leadership that creates an enabling environment for development. For instance across the whole globe civilians are protesting. Common themes towards the protests revolve around concerns over inequalities, corruption, poor public services, fraudulent elections, human rights abuses and repression among others. Institutional systematic change is required and improvement on the quality of political leadership. There is substantial risks of massive and unjustified disappointment of the citizens if the ARFSD approaches and outcomes fail to adequately deal with these problems and challenges in the 2020-2030 decade and in the future.

Lack of preparedness on how to deal with pandemics such as natural disasters like cyclone Idai and Kenneth in 2019 and Corona Virus disease (COVID-19) as the case with Africa in 2020 continue to pause a lot of challenges towards the intended outcomes of the SDGs approach. According to the Centre for Disease Control (CDC) and World Health Organisation (WHO) Corona Virus (COVID-19) is a severe illness that had spread throughout the globe. The spread of Corona Virus has affected development in the whole world causing a number of countries to lockdown their economies to prevent the spread. Other measures included staying at home, social distancing, closure of operations not in the essential services and general practise of hygiene all the times. Efforts made earlier on improving health in Africa has been thrown in the doldrums and it is impossible to meet the targets of the SDGs by 2030. Indeed development in Africa has again gone into the reverse after several pandemics hit the continent. Across, COVID -19 has hit the African continent and is expected to trigger the first recession in sub-Sahara Africa in 25 years (Bodewing, Gentilini, Usman \& Williams, 2020) impacting negatively on the capabilities and opportunities on which Africa can exploit to meet the SDGs by 2030. The Secretary General of the United Nations says this is now a decisive moment. The African Union Report on SDGs (2020) is an opportunity to mark the decade long route to meet the SDGs by 2030. Strong support can assist towards meeting the SDGs. There are some fastest economic growth where poverty declining has been noted to have declined from $34.5 \%$ in 2015 to $32.5 \%$ in 2019. However, Sachs (2019) is convinced that poverty and food insecurity is on the increase. In July 2019, the Heads of State and Government in their Political Declaration of the 2019 Sustainable Development Goals' Summit called for urgent concerted and accelerated action by all stakeholders at all levels to achieve the 2030 Agenda. Given its focus on actions to transform Africa in the decade ahead, the sixth session of the Regional Forum was well-placed to provide a platform to raise awareness of such actions at national government level and among non-State actors. The 
actions comprise of initiatives voluntarily undertaken to accelerate the SDG implementation.

\subsection{The Challenges towards Sustainable Development on the African Context}

The desire and commitment to meet the SDGs goals by Africa has been stalled by a number of challenges. ITUC-Africa (2020) presented some challenges to the outcomes of Africa`s initiatives towards development and the limitations of the outcomes and approaches of the ARFSD. Singh (2016) says the challenges for achieving SDGs include lack of effective leadership, coordinated partnerships, lack of investments, implementation and indicators with effective data collection. It provided that Africa faces a lot of challenges to meaningfully implement the SDGs as there still exist a wide gap between what the two agendas demand and the realities on the ground (ITUC-Africa, 2020). Ratification of the Agendas and funding of the same at country level still remains a challenge on the part of African countries (ITUC-Africa, 2020). Hence lack of commitment towards development is seen at all levels. Monitoring and reviewing of progress on the African context remains voluntary and as such there is no push towards development on the basis of the approaches and outcomes of the African modalities towards development (ITUC-Africa, 2020). Many African countries do not process developmental data hence data in Africa remains scarce, incomplete and inconsistent where it exists (Singh, 2016; ITUC-Africa, 2020). Lacking is the political will by Africa to institute reforms that create a good environment to support full implementation of the SDGs.

The lack of effective leadership is linked to governance which refers to the supporting regulatory, policy frameworks and accountability mechanisms on the implementation of the SDGs at national, regional or global level. According to the Sustainable Development Goals Centre for Africa (2019), governance involves appropriate operational guidance, supporting effective coordination and collaboration of all stakeholders, trade off discussions and accountability. However, despite the efforts done in implementation of the 2030 SDG Agenda, overall progress is off track. The Organisation for Economic Cooperation and Development (OECD, 2018) says the slow progress is due in part to the weak SDG governance framework. The UN (2017) states that due to the complexity nature of the Agenda 2030 there are no proper governance structures to enforce implementation of the goals. Efforts directed to good governance have largely been restricted to civil servants and civil service capacity building. There is no sufficient, systematic attention to building skills and capacity among those holding office yet they drive policy making. Organization for Economic Cooperation and Development wrote that,

"delivering on the sustainable development goals is a formidable governance challenge for countries at all levels of development. Leadership for SDGs and sustainable development is on the hub of governance. Improved governance and up skilled ministerial leadership is needed to empower and capacitate governments, drive policy change and implementation" (OECD, 2018).

Furthermore, there are data gaps as the national or international database is very scarce, incomprehensive and inconsistent where it exists (SDGs Index and Dashboard Report, 2019, SDG/CA, 2019). The report reinforces that methodological and data gaps prevail as half of the 
169 indicators are not quantified while only $40 \%$ of the indicators in the SDGs framework have data. Africa needs to do its own assessment other than waiting for statistics from New York as many African countries do not possess updated data for crucial indicators like poverty, health, nutrition, education and infrastructure (SDGs Index and Dashboard Report, 2019).

Climate change effects imply that development is falling. New approaches are needed quickly on tackling the challenges. It remains questionable how unsustainable development is contracting growth. The climate change has affected economic growth which declined from $6.8 \%$ to $-4 \%$ (ECA, 2020). Climate change has a negative impact on economic growth and development in Africa. Hence Africa needs to be more innovative in its programming, planning and fight against the effects of climate change. Nwatitu discussing on effects of climate change said, "climate change is now a reality" (ECA/ARFSD, 2020). There are several challenges with regards to protecting the environment.

Analysing the progress made so far on an African perspective, Songwe, the Executive Secretary of ECA said "Africa had it all, and needed to succeed in achieving sustainable development" (ECA/ARFSD, 2020). Songwe provided that the obstacles are many which included climate change, diseases including Covid-19 and trade challenges. She added that Africa`s young people needed 13 million jobs per year and it is the business and private sectors that should create these jobs. Added to these challenges, Ouafi stressed that African countries had made substantial but insufficient progress in implementing the sustainable development goals (ECA/ARFSD, 2020). Ouafi stressed that, while many African countries have included both the 2030 Agenda and Agenda 2063 in their national development frameworks, the main challenge continued to be mobilizing funding for implementing the two Agendas. There are too many plans and approaches that the African governments with their very limited resources are attempting to do at the same time. There is an attempt to adopt the universal development approach premised on the United Nations approach to development while at the same time adopting the SDGs approach in the wake of nationalising Agenda 2030 and 2063 Agenda into the national developmental programmes at country level. Singh (2016) provided that while SDGs have been accepted in principle, they have been criticised for being too large in number and too wide in scope making it a challenge to create and raise awareness, mobilization and advocacy. However, Morocco is an example noted to have successfully developed a national sustainable development strategy which served as a reference framework for implementing the SDGs. Despite that, Quartey noted that progress with regard to SDGs had been mixed and uneven (ECA/ARFSD, 2020).

Despite the notable track record on declining poverty rates, gains made in health and education sectors and the continued joint approaches between the African Union and The United Nations in reinforcing implementation, reviewing, reporting and resource mobilisation with regards to Agenda 2030 and 2063 Agenda, Africa still is not on track to meet the SDGs (UNECA, 2020). Corruption and lack of credible data sources were singled as other critical impediments of sustainable development strategies on the part of Africa.

While progress on other goals was noted especially goal number 4 there has been slower progress on other goals in the different African contexts. Barely there had been any reduction 
in inequality, which continued to have a negative effect on peace and security. According to the Africa Sustainable Development Report (2019) focusing on the SDGs looking at the principles of people, prosperity, planet, peace and partnerships alongside the different dimensions of sustainable development, economic, social and environmental pillars, there has been mixed progress (Africa Sustainable Development Report, 2019). Africa might not meet the targets if scaling up does not occur. In light of all these initiatives and approaches, Ahmed (2018) notes that there has been no doubt that there has been no shortage of global agenda and in particular, there has been a dozen of special international initiatives on Africa since 1980. However, thus far they have not worked. Poverty and inequality continue to rise (Sachs, 2015). Due to the problems caused by the public health COVID-19 pandemic, the levels of poverty increased with a number of people in the developing countries resenting against the lockdown measures meant to reduce the spread of the virus. Another key challenge is the structural nature of the problems associated with the SDG framework itself where the several targets are aspirational and unachievable for instance target, 3.2 on ending preventable deaths of new-born and under five children, target 3.3 to end the epidemics of AIDS, TB and malaria ( Singh, 2016). These are not achievable and they remain a chief obstacle along the way.

\subsection{The Forum's Key Messages, Alternatives and Strategies}

A number of key messages were suggested to the High Level Political Forum referring to the possible alternatives and strategies Africa should focus on if it needs to achieve the SDGs. The key messages were provided on the backdrop of all 17 goals clustered into five "ps", people, prosperity, planet, peace and partnerships on the pretext that Africa was not on track to achieve goals by 2030. A summary of the key messages comprised of priorities, policy options and recommendations as highlighted below.

\subsubsection{Alternative Energy}

The forum suggested that there is need for provision of alternative energy sources that ensure and guarantee effective alternative sources of energy for both people in the urban and rural areas.

\subsubsection{Equality and Education}

There should be reduced inequalities through provision and full access to quality education and vocational training services. Technical Vocational Education and Training provision becomes key to enhancing employability to the general critical mass.

\subsubsection{Decent Work and Employment Opportunities}

Regarding decent work there is need to design and implement pro-decent employment opportunities, progressive minimum wage policies, social dialogue and legislative mechanisms.

\subsubsection{Industrialization and Economic Growth}

As with industrialization the efforts to promote economic growth and a paradigm shift 
towards value addition against the neo-liberal agenda that promotes export of primary commodities was suggested.

\subsubsection{Infrastructure and Settlements}

The need to have combined industrial infrastructure and combined cities was singled out as an important area where many countries need to focus on and improve.

\subsubsection{Climate Action and Environment}

It was suggested that Africa should adopt climate resilient infrastructure. Furthermore, Africa should be more assertive regarding the global community resources for it to achieve sustainable development. (ECA/ARFSD, 2020).

\subsubsection{Other Key Messages}

Other key messages were prepared from more than 60 preparatory and side events organised during the regional forum. The High Level Political Forum discussed and considered high inequalities on income, gender, declining natural environment and the negative impact of climate change. It discussed that the Agenda 2063 has similar impact on SDGs (ECA/ARFSD, 2020) looking at ambitions that national plans, policies and institutions put in place to assist in meeting the SDGs. Prudent was the suggestion to include the national financing alternatives, involvement of the general public towards SGDs and their active participation. The need for positive engagement to fight against corruption, use technology to improve on transparency and private sector involvement were considered important.

Other highlights cutting across a number of SDGs revolved around devolution of government structures as the implementation of the SDGs going forward. Devolution process was suggested to allow vigorous implementation of the SDGs throughout African member states as it fosters decentralisation and localisation of planning and resourcing (ECA/ARFSD, 2020). The national priority was suggested to be integrating the national policies into the Agenda 2030 and 2063 Agenda in the 2020-2030 decade of programming and planning. Agro-based industrialisation is the bedrock through which Africa can achieve the SDGs. The $4^{\text {th }}$ Industrial Revolution, SDG 4 and 9, industrial innovation, higher and tertiary education, established innovation, incubation hubs across the continent are all critical hence the need to empower small, medium enterprises and the informal sector as well.

Rural transformation is important. There is need to exploit on the investment opportunity anchored on bringing technology in the rural areas to attract young people who are migrating into town. Subsequently it also helps to reduce pressure exerted on urban areas leading to shanty cities or settlements. Supporting rural agriculture especially the small holder farmers and creation of agro-based industries in the rural areas helps to create sustainable agriculture in the rural areas. For example 50\% of poultry is coming from smallholders, there is need to treat every enterprise as a business not pleasure, keeping records straight, hiring engineers and experts to assist in such business, women are better managers of resources. Imperatively, there is need to empower women and involve young people. However, there are questions regarding programming versus sustainability in the rural areas. There are also malnutrition 
challenges where there is no empowerment for food fortification. There is also need for integrated water management system as farmers are not able to conform to farming standards. Technology however excludes other people in the rural areas. Hence people may then become more vulnerable.

In view of this, ITUC-Africa (2020) submits that for sustainable development to be achieved in the 2020 to 2030 decade, a rights based approach to sustainable development is needed. ITUC-Africa argued that labour standards must be guaranteed for all if SDGs are to be met as it helps to uphold freedoms of association, collective bargaining rights, social protection and social dialogue. Human rights and labour rights are pillars of functional democracy, argues ITUC-Africa. With the rights based approach, it is assumed it allows for calls for a new social contract for governments, business and workers anchored on a Universal Labour Guarantee that provides protection floors for all workers. It is argued, this helps the two agendas to be transformative and progressive. ITUC-Africa emphasized that Universal Labour Guarantee ensures that workers' rights, women's rights and children's rights are equally respected, jobs are decent, with minimum living wages and collective bargaining processes provided where workers have control over working time and a universal social protection coverage. Furthermore, ITUC-Africa suggested that the International Labour Organisation (ILO) Decent Work Agenda with its four pillars needs to be embedded within the SDGs framework as it is a comprehensive agenda for eradication of poverty, promotion of prosperity in the changing world and it interconnects all the SDGs. Thus the ILO Decent Work Agenda helps to lift people out of poverty, improve incomes and livelihoods, offers a universal social protection and enhances social dialogue hence promoting democracy and peaceful societies where people live together harmoniously.

With specific reference to the climate change, subsequently, the following issues were suggested. That there is need to find the balance and create linkages between climate and equality as this has not been considered in any attempt to deal with climate change effects at the African context yet climate change is a reality and is causing a lot of suffering and inequalities. There need for planning, funding, and implementation are critically important.

Some emerging action points that involved strengthening social protection systems at a global level to fight poverty, reduce vulnerability and risks were consolidated. Universal social protection system as suggested by the International Labour Organisation and the United Nations system is critical.

\section{Recommendations}

People across the globe vary in their perspectives and a universal people centered approach proved difficult thereby jeopardising success and progress made towards meeting the SDGs at some levels. However, the universal people approach contained within the SDG framework gives potential for Africa to have her own home grown solutions to own challenges. Social protection systems that include the youth, women and elderly are important as a cross cutting issue applying to all SDGs.

Building coalitions and strong partnerships that involve the private, public sectors, state 
actors, non-state actors, youth, women, civil society, non-governmental organisations, profit and non-profit making organisations. It is critically important to endeavor making Africa a transformed and prosperous continent by 2030 by encouraging functional North-South and South-South cooperation and linkages.

Monitoring, recording and reporting of the experiences, knowledge shared and expertise exchanged become an essential issue that involves engaging with sectors that are involved in inequalities and ensuring that they participate.

The people centered approach to development involves several multilevel hence we need to look at the inter-linkages of the SDGs, interconnected issues, hunger, poverty, malnutrition, gender among other things.

As SDGs assigns a commitment to both poor and rich countries as assumed, ending global poverty by 2030 requires a concerted effort of both. The commitment of African poor countries is to take ending poverty and achieving all SDGs seriously and devote greater share of their national resources towards such initiatives whereas the rich countries need to move beyond just help but to follow through with repeated help until the SDGs are achieved.

There is need for a strong global framework to end global poverty confined in a contract of "global compact" between the rich and the poor. The suggested Sustainable Development Goal- End to Global Poverty Framework that all poor countries can adopt and rich countries can repeatedly fund premised on good governance that attracts assistance and commitment to be fully responsible partners on the part of the rich countries.

Africa`s potential is in agriculture, mining and manufacturing industries which should be integrated at all levels. This implies that Africa should endeavor to enhance rural development as the majority of the African population is in the rural areas and Africa needs to develop new and sustainable energy alternatives that supports agriculture mining and manufacturing through the support of agro-processing industries that adds value to the agriculture and mining sectors primary products.

Africa should include the women, youth and marginalised poor people in all its planning and programming and ensure that they are adequately protected with strong social protection systems at all levels. Hence broad-based, inclusive, diverse and universal approaches to social protection should be adopted at continental level to help fight poverty, vulnerabilities and inequalities and instabilities. Social protection is important in that it cuts across all the 17 SDGs.

\section{Conclusion.}

Africa needs to know how best to achieve all the 17 SDGs after it had turned out in 2015 that Africa was far away from achieving the MDGs. Without a clear strategy to fight poverty, inequalities, gender disparities, climate change effects, development of dirty, shanty cities and settlements, food insecurity, health and energy challenges, it becomes impossible to turn around Africa to a transformed and prosperous continent which is united, strong, stable and a great player in international politics, economics, trade and as a partner that can give aid to 
others countries. New, comprehensive, clearly thought out inclusive indigenous African alternatives to development that are pro-poor and broad-based are needed for Africa. Strong and equitable partnerships are central on African developmental trajectories. Two thirds of Africa is vast, unused arable land that gives Africa the potential to grow sustainable food that would feed the whole world and be a strong trade partner on food. Africa needs to exploit its potential to the fullest without blaming the past.

\section{References}

African Union. (2020, February 10). Launch of the First Continental Report on Implimentation of Agenda 2063.

Ahmed, D. (2018). "Re-possessing Africa, New Approaches to Leadership, Governance and Democracy", Critical Implications for Public Policy. Journal of African Studies and Development.

Barcena, A., Prado, A., Yanez, L. F., \& Perez, R. (2017). Annual Report on Regional Progress and Challenges in Relation to the Agenda 2030 for Sustainable Development in Latin America and the Caribbean. Forum of the Countries of Latin America and Caribbean on Sustainable Development. Mexico: United Nations.

Bettencourt, L. M., \& Kaur, J. (2011). Evolution and Structure of Sustainability Science. Sustainability, 11. https://doi.org/10.1073/pnas.1102712108

Bodewig, C., Gentilini, U., Usman, Z., \& Wiliiams, P. (2020, May 12). COVID-19 in Africa: How can Social Safety Nets help Mitigate the Social and Economic Impacts? Retrieved 2020, from Africa Can Poverty: https://blogs.worldbank.org/africacan/covid-19-africa-how-can-social-safety-nets-help-mitiga te-social-and-economic-impacts

Cerf, M. (2018). The Sustainable Development Goals: Contextualizing Africa`s Economic and Health Landscape. Global Challenges, Sustainable Healthcare. https://doi.org/10.1002/gch2.201800014

Easterly, W. (2015). The Trouble With Sustainable Development Goals. Current History, 114, 775. https://doi.org/10.1525/curh.2015.114.775.322

Emas, R. (2015). The Concept of Sustainable Development: Definition and Defining Principles. Florida International University.

Farah, M. H., \& Sabani, A. (2019, April 3-5). Towards Sustainable Development Goals: A Literature Review and a Conceptual Framework of Governance Issues in Africa. Proceedings of the 12th International Conference on Theoryand Practice of Electronic Governance. https://doi.org/10.1145/3326365.3326392

Given, M. L. (2008). The Sage Encyclopedia of Qualitative Research Methods (Vol. 1 \& 2). SAGE. https://doi.org/10.4135/9781412963909

Global Sustainable Development Goal Report. (2019). 
Horoszwski, M. (2015, September 10). The Full List of the 17 United Nations Sustainable Development Goals.

ICSU; ISSC. (2015). Review of Sustainable Development Goals. The Science Perspective.

ITUC-Africa. (2020). Trade Unions Vision On the Sustainable Development Goals."2020-2030 A Decade to Deliver a Transformed and Prosperous Africa through the 2030 Agenda and Agenda 2063". Sixth Session of the Africa Regional Forum on Sustainable Development. ITUC-Africa.

Jaiyesimi, R. (2016). The Challenge of Implimenting the Sustainable Development Goals in Africa: The Way Forward. African Journal of Public Health, 20(3), 13. https://doi.org/10.29063/ajrh2016/v20i3.1

Johnes, P., Wynn, M., Hillier, D., \& Comfort, D. (2017). The Sustainable Development Goals and Information Communication Technologies. Indonesia Journal of Sustainability, Accounting and Management, 1(1), 1-15. https://doi.org/10.28992/ijsam.v1i1.22

Jolly, R., \& Santos, R. (2016, May). From Development of the "Other" to Global Governance for Universal and Sustainable Development. Development Studies, Past, Present and Future, 47(2). https://doi.org/10.19088/1968-2016.129

Leach, M. (2016). 'Introduction: States, Markets and Society-Looking Back to Look Forward". IDS Bulletin, 47(2A), 1-18. https://doi.org/10.19088/1968-2016.175

Longhurst, R. (2017). " Has Universal Development Come of Age?" Universal DevelopmentResearch and Practice. Institute of Development Studies Bulletin, 48(1A).

Masundire, H. (2008). The Ecosystem Approach to Sustainable Development. Achieving Sustainable Development and Promoting Development Cooperation, Dialogues at the Economic and Social Council.

Mensah, J., \& Casadevall, S. (2019). Sustainable Development: Meaning, History,Principles, Pillars and Implicationsfor Human Action, Literature Review. Cogent Social Sciences, 5(1). https://doi.org/10.1080/23311886.2019.1653531

Moatti, J. P. (2020, February 15). Opinion. United Nations Expert Group Member Opinions.

Mueller, A. (2008). Increasing Populations and Increasing Scarcityof Food, Natural Resources and Energy. Achieving Sustainable Development and Promoting Development Coorporation, Dialogues at the Economic and Social Council., 1.

OECD. (2018). Global Outlook on Financing for Sustainable Development 2019. Time to face the Challenges. Retrieved from https://doi.org/10.17879789264307995-en

Redclift, M. (2005). Sustainable Development (1987-2005). An Oxymoroncomes of age. Sustainable Development, 13, 212-227. https://doi.org/10.1002/sd.281

Sachs, J. (2015). The End Of Poverty. How We Can Make It Happen In Our Lifetime. Ranch House: Penguin Books. 
Sachs, J. (2019). Lecture on Food, Agriculture and Sustainable Development. Ending Food Insecurity, The Food and Agriculture Organisation of the United Nations and Sustainable Development Goals. University of Columbia.

SDG Center for Africa and Sustainable Development Solutions Network. (2019). 2019 Africa SDG Index and Dashboard Report.

SDG Center for Africa. (2019). Africa 2030: Sustainable Development Goals: Three Year Reality Check. Retrieved from http://sdgcafrica.org/wp-content/

Shi, L., Han, L., Yang, F., \& Gao, L. (2019). The Evolution of Sustainable Development Theory: Types, Goals and Research Prospects. Sustainability. https://doi.org/10.3390/su11247158

Shumba, D. (2017). Risk, Resilience and Sustainability: How Governance in Zimbabwe Counterveils this Nexus. Journal of Sustainable Development., 17(1), 169-219.

Simone, F., \& Clark, H. (2020, January 03). "Global Views on Sustainable Development". Opinion. Devex.

Singh, Z. (2016). Sustainable Development Goals: Challenges and Opportunities. Indian Journal of Public Health, 60, 247-8. https://doi.org/10.4103/0019-557X.195862

Spaiser, V., Ranganathan, S., Swain, R., \& Sumpter, D. (2016). The Sustainable Development Oxymoron: Quantifying and modelling the incompatibility of sustainable development goals. International Journal of Sustainable Development World Ecology, 24, 457-470. https://doi.org/10.2139/ssrn.2766875

Stern, D., Common, M., \& Barbier, E. (1996). Economic Growth and Environmental Degradation: The Environmental Kuznets Curve and Sustainable Development. World Developement, 24, 1151-1160. https://doi.org/10.1080/13504509.2019.1692316

Swain, B., \& Wallentin-Yang, F. (2020). Achieving Sustainable Development Goals: Predicaments and Startegies. International Journal of Sustainable Development and World Ecology, 27(2), 96-106. https://doi.org/10.1080/13504509.2019.1692316

Todaro, P. M., \& Smith, C. S. (2011). Economic Development. New York: Pearson.

UN SDSN. (2015). Data for Development. A needs Assessment for SDG monitoring and statstical capacity development .Technical Report. UNSDSN.

United Nations Economic Commission for Africa. (2020). Sustainable Development Goals. Sixth Session of the Africa Regional Forum on Sustainable Development (ARFSD-6). Forum Bulletin. ARFSD.

United Nations. (2013, July). United Nations General Assemby Report of the Secretary General. Retrieved from http://www.un.org/en/ga/search/view 


\section{Copyright Disclaimer}

Copyright for this article is retained by the author(s), with first publication rights granted to the journal.

This is an open-access article distributed under the terms and conditions of the Creative Commons Attribution license (http://creativecommons.org/licenses/by/4.0/). 